Association for the Advancement of Science in these questions is well known, and a representative delegation from that body is expected at Cambridge to confer with the officers of the British Association upon the ways and means of closer co-operation. The report of the committee will be circulated early in August to all members of the General Committee known to intend to be present at the meeting. The same committee of the Council was charged with a review of the methods of publication at present practised by the Association, the principal medium being the annual report, which many people have long regarded as a graveyard of scientific communications the relegation of which thereto not infrequently appears to be something less than they deserve. A far-reaching proposal will be put forward in this connexion.

It will be apparent from previous announcements that the scientific programme will be full of worthy subjects, and one not previously mentioned calls for notice here. The visit of the scientific delegation to India last winter was so notable an episode that it has been felt to call for due recognition at Cambridge, and it is hoped to hold a special meeting, with Sir James Jeans, the jubilee president of the Indian Science Congress Association, in the chair, at which some of the delegates will give their impressions of the tour. Also an exhibition of photographs taken by delegates will be displayed in the reception room; the party was fortunate in including a number of very skilful amateur photographers. Another unaccustomed exhibition will be that of paintings and drawings by members of the Association, some of whom are already well known as artists in their hours of relaxation, though hitherto there has been too little opportunity to appreciate their work.

In certain directions, therefore, the Cambridge meeting may be expected to add materially to the history of the Association. In one other, it will assuredly do so. For the first time, a sherry party finds place in the official programme. It will be given in Emmanuel College by the Mayor and Mayoress of Cambridge-a very welcome innovation.

Among other social functions will be a reception by the University in the Senate House and Old Schools on Thursday evening, August 18. There will be informal conversaziones in Trinity College on Friday evening, August 19, and in St. John's College on Monday evening, August 22. Garden parties will be held in Downing College and Sidney Sussex College on Friday afternoon, August 19, and in Christ's College and Queens' College on Monday afternoon, August 22.

Full details of the social functions will be published in the programme and time-table.

\title{
The Piltdown Man Discovery
}

\section{Unveiling of a Monolith Memorial}

$\mathrm{O}^{\mathrm{N}}$ July 23, Sir Arthur Keith unveiled a monolith memorial which has been placed in the grounds of Barkham Manor, Piltdown, Sussex, to mark the spot where the late Mr. Charles Dawson found the fossil skull of Piltdown Man (Eoanthropus dawsoni). He paid a tribute to Mr. Dawson, whose important work as an amateur deserved our gratitude and remembrance. $\mathrm{He}$ remarked that the Piltdown skull is so different from any other human skull previously discovered, that the divergent opinions expressed by those who have attempted to interpret it are not surprising. In 1912-1913, when the fossil was found, much less was known of early man than is known at present. If a similarly novel discovery were made now, there would be closer agreement among those who studied it. Sir Arthur is more impressed at present with the simian characters of the skull and brain-cast, as well as those of the lower jaw, than he was when he originally examined the fossil.

After the unveiling, Sir Arthur Smith Woodward gave some reminiscences of his collaboration with Mr. Dawson at Piltdown, and he added that the first subscription towards the memorial was received from the late Prof. Henry Fairfield Osborn, of New York. Brigadier-General E. G. Godfrey-Faussett, chairman of Council of the Sussex Archæological Society, spoke of the generosity of landowners to archæologists, and expressed thanks to Mr. D. Kerr of Barkham Manor. The memorial was designed by Mr. Percival Bridgman of Lewes, and is made of durable Carboniferous sandstone from Yorkshire.

The following is the substance of Sir Arthur Keith's speech :

Mr. Charles Dawson-solicitor and antiquarianhas been in his grave these twenty-two years; he 
died in 1916 at the age of fifty-two, but the discovery he made on the spot where we are now assembled, the fossil remains of the earliest Englishman known to us, goes on growing in magnitude and in importance. The fossil bones he gathered here from a heap of road metal by the wayside-the private way leading to Barkham Manor-gave us the entrance to a long-past world of humanity, such a world as had never been dreamt of by anyone in England or in any other land.

I have in my hand a guide book to Sussex published in 1911. It was written by my learned friend-the late Mr. A. R. Hope Moncrieff. He assured his readers that the earliest inhabitants of Sussex were the 'celtic tribes', whose camps can still be traced on the Downs. When these words were being written by Mr. Moncrieff, Mr. Dawson was assembling evidence that carried the history of man in Sussex back to a remote period-one to which geologists assign a duration of half a million of years-or perhaps twice that amount. This discovery was not sent to Mr. Dawson by the fickle goddess, chance; it came to him because knowledge knew how to use its opportunities. The Weald was then alive with antiquaries, searching for the handiwork of ancient man. Mr. Dawson had his own beat, and searching for implements in that beat, he met with the fossil remains of a maker of the older stone implements.

The greater the novelty of a discovery, the more it departs from ascertained knowledge, the greater is the difficulty of getting it into its right perspective and the longer is the time needed to reach that end. More than ninety years ago an exciseman named Boucher de Perthes found worked stone implements in ancient deposits in the Somme Valley; it took seventy years to prove that what was true of the ancient deposits of the Somme Valley is repeated in every great river valley of the Old World. In 1857, when Neanderthal man was discovered, diverse explanations were given to account for the brutality of his structure ; it took half a century of exploration to place him in his proper place in history. $\mathrm{He}$ proved to be a representative of the Europeans of a remote period, the period which saw the onset of the last glaciation of Europe.

The fossil remains found at Piltdown by $\mathrm{Mr}$. Dawson set students of man's evolution the most difficult task that has confronted them hitherto. In his characterization, Piltdown man was quite unlike any fossil type known to us. Sir Arthur Smith Woodward was impressed by his simian similarities; I, on the other hand, was impressed by those features which, as I thought then, were eminently human and modern. Hence arose those discrepancies between us-discrepancies of a quarter of a century ago.

Since then, much has happened. Discoveries are being made which help to throw Piltdown man into his proper place in the crowded throng of evolving human forms. We now know that when the Piltdown type was being evolved in England-or at the western end of the Old World-a totally different type had come into being in the Eastern lands of the old World. The Eastern types had low receding foreheads, modelled as in the gorilla and chimpanzee.
The Western or Piltdown type differed; it had a relatively upright and high forehead, modelled not on gorilla lines but rather on those of the orang. While the Eastern forms retained in their shape of head the low squat type of the chimpanzee and gorilla, the Western or Piltdown type tended to assume the higher vaulted skull seen in modern races. There is no denying that in many of his features Piltdown man foreshadowed some of the structural modifications we find in modern races of mankind. Sir Arthur Smith Woodward, I know, will agree with me as to how Piltdown man came by such

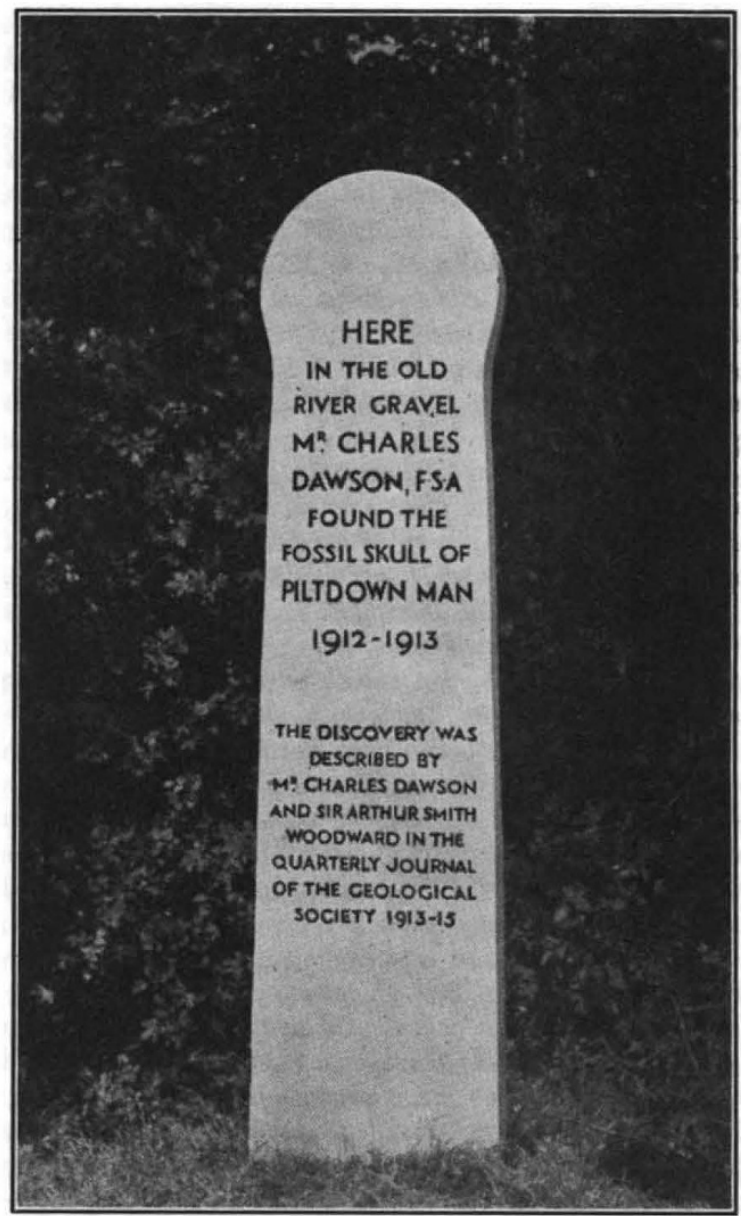

Reeves, photo, Lewes.

features: he came by them independently, for discoveries of recent years have proved that diverse races of mankind have undergone the same structural change quite independently of each other. And there is also no denying that through all his known parts there runs a simian vein in Piltdown man, in his skull and brain as well as in his mandible.

So long as man is interested in his long past history, in the vicissitudes which our early forerunners passed through, and the varying fate which overtook them, the name of Charles Dawson is certain of remembrance. We do well to link his name to this picturesque corner of Sussex-the scene of his discovery. I have now the honour of unveiling this monolith dedicated to his memory. 